\title{
Shifted Firefighter Health Investigation by Personal Health Insurance Record in Taiwan
}

This article was published in the following Dove Press journal:

Risk Management and Healthcare Policy

\author{
Wei-Ching Hsu ${ }^{1,2}$ \\ Chun-Hsiang Wang ${ }^{3}$ \\ Kang-Ming Chang ${ }^{4-6}$ \\ Li-Wei Chou (D) ${ }^{2,7,8}$ \\ 'Department of Bioinformatics and \\ Medical Engineering, Asia University, \\ Taichung, Taiwan; ${ }^{2}$ Department of \\ Physical Medicine and Rehabilitation, Asia \\ University Hospital, Asia University, \\ Taichung, Taiwan; ${ }^{3}$ Fire Bureau of \\ Taichung City Government, Taichung, \\ Taiwan; ${ }^{4}$ Department of Computer \\ Science and Information Engineering, Asia \\ University, Taichung, Taiwan; \\ ${ }^{5}$ Department of Medical Research, China \\ Medical University Hospital, China \\ Medical University, Taichung, Taiwan; \\ ${ }^{6}$ Department of Digital Media Design, \\ Asia University, Taichung, Taiwan; \\ ${ }^{7}$ Department of Physical Medicine and \\ Rehabilitation, China Medical University \\ Hospital, Taichung, Taiwan; ${ }^{8}$ Department \\ of Physical Therapy and Graduate \\ Institute of Rehabilitation Science, China \\ Medical University, Taichung, Taiwan
}

Introduction: Taiwan's firefighters use a shift rotation system with 2 days of work and 1 day of rest. Numerous papers have already explored the risks of shift work to the body. However, little data concern the impact of shift work on health as reflected in medical visits. This study used individuals' medical visit record in Taiwan's health insurance system. The locally called "health bank" contains individuals' medical visit record, health insurance payment points and the medicine used.

Methods: Consent was obtained from 150 firefighters who were serving under the shift rotation system to obtain their 2015 individual "My Health Bank" medical data. Comparisons were made between national health insurance data norm.

Results: Firefighters make significantly more visits for Western medicine than the annual average (firefighters 6.27 vs norm 5.24, $\mathrm{P}=0.04142$ ), more total number of medical visits (9.57 vs 7.75, $\mathrm{P}=0.0102)$, more annual average payment points for Western medicine (4079 vs $2741, \mathrm{P}=0.003151$ ), and a greater average number of total annual medical visit points (7003 vs 4940, $p=0.0003157$ ). Firefighters had significantly higher incidents of respiratory diseases, urogenital diseases, skin and subcutaneous tissue diseases, musculoskeletal system and connective tissue diseases, injuries, and illness from poisoning than did the norm $(\mathrm{P}<0.05)$.

Conclusion: A persuasive health-survey-based method for workers in high occupational hazard industries was proposed in this study, and the result was highly correlated with risk factors of fireworkers. The proposed study method is potential to investigate risk factors of other working.

Keywords: firefighters, shift worker, health insurance record

\section{Introduction}

The shift rotation system is a work pattern that is necessary in many fields, particularly for workers who often work at night for long periods of time. However, long-term shift rotations have a negative impact on workers' health. ${ }^{1,2}$ Firefighters work under the shift rotation system, and the long-term shift rotations have a significant impact on their sleep ${ }^{3}$ and psychological stress. ${ }^{4}$ Because frontline firefighters must protect the life and assets of the public and arrive at incident sites immediately, they must be on call during the shift rotation system. In addition, uncertainty in different types of disaster sites significantly affects the physical and mental health of disaster rescue personnel, and this can cause many types of occupational hazards and diseases. Taiwan's firefighters shift rotation system is based on a work pattern of 2 days of work and 1 day of rest (working for 48 $\mathrm{h}$ and resting for $24 \mathrm{~h}$ ). In Taiwan, $40 \%$ of firefighters have gastrointestinal diseases,
Correspondence: Kang-Ming Chang Information of Computer Science and 500, Lioufeng Road, Wufeng, Taichung, 41354, Taiwan

Tel +886-4-23323456

Fax +886-4-23316699

Email changkm@asia.edu.tw

Li-Wei Chou

Department of Physical Medicine and

Rehabilitation, China Medical University

Hospital, No. 9I, Hsueh-Shih Road,

Taichung, 40402, Taiwan

Tel +886-4-22053366

Fax +886-4-23316699

Email chouliwe@gmail.com
Risk Management and Healthcare Policy 202I:14 665-673

665

DovePress $f y$ in $\boldsymbol{v}$ 
followed in percentage by respiratory system diseases, high blood pressure, and liver diseases. Injuries to the hands (arms) and feet (legs) account for most work-related injuries (approximately 50\%), followed by waist (hip) injuries $(20 \%){ }^{5}$ Thus, the health problems of shift rotation firefighters remain a focus for academia. ${ }^{6}$ Table 1 lists recent studies on occupational injuries that are related to firefighters and shift rotations. These mainly involve sleeping, ${ }^{14,15}$ depression and stress, ${ }^{16,17}$ cognitive functions, ${ }^{18}$ cancer, ${ }^{19,20}$ hypertension, ${ }^{21}$ physical activity and obesity, ${ }^{22-24}$ metabolic syndromes, ${ }^{25}$ and injuries and musculoskeletal disorders. ${ }^{26,27}$ According to the 2154 work

Table I Recent Studies on Occupational Injuries That are Related to Firefighters and Shift Rotations

\begin{tabular}{|c|c|c|c|c|c|}
\hline $\begin{array}{l}\text { Ref } \\
\text { no. }\end{array}$ & Year & Country & Subjects & Stuy Method & Major Finding \\
\hline 16 & 2008 & japan & $\begin{array}{l}\text { I30| shift-work } \\
\text { firefighters. }\end{array}$ & CES-D; job dissatisfaction survey & $\begin{array}{l}\text { Workload, intergroup conflict, social } \\
\text { support from a supervisor related to } \\
\text { depressive symptoms and/or job } \\
\text { dissatisfaction }\end{array}$ \\
\hline 14 & 2018 & Iranian & $\begin{array}{l}60 \text { shift work } \\
\text { firefighters }\end{array}$ & melatonin, sleepness & Melatonin level change at 3:00 and 7:00 \\
\hline 15 & 2017 & Korea & $\begin{array}{l}\text { I } 10 \text { shift work } \\
\text { firefighters }\end{array}$ & $\begin{array}{l}\text { Pittsburgh Sleep Quality Index, the Insomnia } \\
\text { Severity Index, the Epworth Sleepiness Score, the } \\
\text { Stanford Sleepiness Score, the Fatigue Severity } \\
\text { Scale, and the Berlin Questionnaire }\end{array}$ & $\begin{array}{l}60 \% \text { of the participating firefighters had } \\
\text { a certain degree of insomnia }\end{array}$ \\
\hline 17 & 2017 & Finland & firefighters & Heart rate variability during shifts. & $\begin{array}{l}\text { Physiological load and psychological stress } \\
\text { were temporarily high }\end{array}$ \\
\hline 18 & 2020 & Poland & $\begin{array}{l}18 \text { paramedics, } \\
16 \text { firefighters } \\
\text { and } 17 \text { day } \\
\text { worker }\end{array}$ & EEG & $\begin{array}{l}\text { Higher amplitude of the P200 and P300 } \\
\text { potential }\end{array}$ \\
\hline 19 & 2018 & Danish & $\begin{array}{l}\text { II,775 } \\
\text { firefighters }\end{array}$ & mortality ratios & Death from stomach cancer increased \\
\hline 21 & 2016 & USA & 330 firefighters & Blood pressure & $\begin{array}{l}\text { Sixteen 24-h shifts had } 5.0 \mathrm{mmHg} \text { higher } \\
\text { DBP }\end{array}$ \\
\hline 22 & 2016 & Australia & $\begin{array}{l}\text { Thirty-four } \\
\text { salaried } \\
\text { firefighters }\end{array}$ & $\begin{array}{l}\text { wore an Actical accelerometer for } 28 \text { consecutive } \\
\text { days }\end{array}$ & $70 \%$ light-intensity physical activity \\
\hline 25 & 2016 & Germany & $\begin{array}{l}97 \text { firefighters } \\
\text { and } 46 \text { office } \\
\text { workers }\end{array}$ & metabolic syndrome & $\begin{array}{l}\text { Sedentary occupation as an office worker } \\
\text { is associated with a high risk of MetS }\end{array}$ \\
\hline 23 & 2017 & Canada & N.A & Veterans' Affairs Wellness kit & Suitability of Veterans' Affairs Wellness kit \\
\hline 24 & 2016 & USA & $\begin{array}{l}308 \text { male } \\
\text { firefighters }\end{array}$ & obesity & Increased the risk for obesity \\
\hline 20 & 2017 & Canada & Review article & Prostate cancer & $\begin{array}{l}\text { Small excess risks of prostate cancer were } \\
\text { observed from firefighter studies with } \\
\text { moderate to substantial heterogeneity }\end{array}$ \\
\hline 26 & 2019 & Ghana & 320 firefighters & musculoskeletal disorders & $\begin{array}{l}\text { Positive effect on musculoskeletal } \\
\text { disorders }\end{array}$ \\
\hline 27 & 2017 & USA & 10,000 & injury & Strains, sprains, and muscular pain. \\
\hline
\end{tabular}


injuries that were recorded from 2010 to 2015 in South Korea in reference, ${ }^{28}$ the majority of injuries concerned the upper and lower back (25.3\%). Such study results were similar to the results of this study. Although the data were from a different country, firefighters do the same work worldwide, and the distribution of common occupational injuries and diseases is similar. However, most studies on the health problems of firefighters have been based on questionnaire surveys. Some studies have focused on specific diseases or physical/mental situations such as by using the Pittsburgh Sleep Quality Index questionnaire to study sleeping problems ${ }^{7}$ or surveys that focus on respiratory tract diseases. ${ }^{2}$ These methods are excellent but can be influenced by the subjective views of the researcher. The interviewees may not accurately reflect topics that the researcher is not focused on, and this can result in omissions. Thus, direct research of interviewees' medical records can offer opportunities to find different answers.

Taiwan has a public health insurance system that includes nearly all residents. Currently, the National Health Insurance Administration (NHIA), Ministry of Health and Welfare, is responsible for its management. To allow the public to sufficiently understand their use of medical resources, convenient channels have been established for the public to access their individual health-care data to conduct individual health management and for them to cherish these medical resources. In 2014, the NHIA introduced the "My Health Bank" information service. Mobile devices such as smart phones or tablet computers can be used to search or download the My Health Bank and check individual health information. This can help achieve self-health management, integrate information from different hospitals/clinics, and allow users to understand their own medical use (to prevent the repeated use of drugs). ${ }^{8}$ My Health Bank can be used to download medical treatment data such as outpatient data, inpatient data, dental health bank data, allergy information, checkup data, images or pathology examination reports, hospital discharge medical records, organ donation or hospice treatment wishes, vaccination bank data, and insurance billing and premium payment information. Similar systems include Australia's Medicare ${ }^{9}$ and the US Department of Veterans Affairs' "Blue Button" individual medical record download plan. ${ }^{10}$ The public can download their own individual medical records and share these with doctors when necessary. ${ }^{11}$ Thus, My Health Bank can be used to collect all patients' medical visit information and prevent researchers' subjectivity from limiting the scope of occupational hazard research.
My Health Bank's disease categorization system is based on the International Statistical Classification of Diseases and Related Health Problems (ICD-9) coding principle. ${ }^{12}$ The ICD-9 categorizes diseases and signs, symptoms, abnormalities, discomfort, social environments, and trauma into 19 categories. By using these 19 categories, the information obtained through My Health Bank, and with firefighters from the Taichung City Fire Department as interview participants, this study compared and analyzed the number of annual medical visits by firefighters (including for Western medicine, Chinese medicine, and dental services, and the total number of such visits), use of Medicare payment points, ICD9CM distribution, and the total number of annual medical visits by the general public for diseases that are published by the Ministry of Health and Welfare ${ }^{11}$ to better understand the health situation of firefighters who work on shift rotations.

\section{Materials and Methods Subject Information}

The participants of this study were field-service firefighters from the Taichung City Fire Department who were working under the 2 day on/1 day off work rotation system (ie, working for $48 \mathrm{~h}$ and resting for $24 \mathrm{~h}$ ). There are 11 firefighting departments in Taichung City, and two departments are chosen to recruit subjects. The A department has 6 units, and B department has 5 units. Total members of these two departments are 223, and 150 subjects agree to participate in this project. This sampling procedure is a kind of cluster sampling. The sampling numbers and proportion of each unit are listed in Table 2. Most subjects are recruited by one of the authors, he is also the member of Fire Bureau of Taichung City Government.

\section{Basic Questionnaire, Health Database Collection, and Data Processing}

This study was divided into two parts. The first part involved the "Individual Basic Information Survey Form." The second part involved collecting individual My Health Bank data by using individual health insurance card logins to the website. The description is as follows:

(1) The Individual Basic Information Survey Form explored firefighters' demographic variables. Each variable contained several choices, as presented in Table 3.

(2) The participants downloaded their individual My Health Bank, and personal information was removed. Frontline researchers coded the information, compiled the medical records, and input the number of 
Table 2 Sample Collection Compilation Table of Participants

\begin{tabular}{|l|l|l|l|l|l|l|l|}
\hline Unit & $\begin{array}{l}\text { Number of } \\
\text { People in the } \\
\text { Unit }\end{array}$ & $\begin{array}{l}\text { Number of } \\
\text { Samples } \\
\text { Collected }\end{array}$ & $\begin{array}{l}\text { Sample } \\
\text { Collection } \\
\text { Rate }\end{array}$ & Unit & $\begin{array}{l}\text { Number of } \\
\text { People in the } \\
\text { Unit }\end{array}$ & $\begin{array}{l}\text { Number of } \\
\text { Samples } \\
\text { Collected }\end{array}$ & $\begin{array}{l}\text { Sample } \\
\text { Collection } \\
\text { Rate }\end{array}$ \\
\hline A1 & 28 & 24 & $85 \%$ & BI & 24 & 13 & \\
A2 & 25 & 22 & $88 \%$ & B2 & 19 & 11 & $54 \%$ \\
A3 & 19 & 12 & $63 \%$ & B3 & 17 & 6 & $58 \%$ \\
A4 & 17 & 15 & $88 \%$ & B4 & 26 & 16 & $35 \%$ \\
A5 & 16 & 14 & $88 \%$ & B5 & 17 & 7 & $62 \%$ \\
A6 & 15 & 10 & $67 \%$ & Total & 223 & 150 & $41 \%$ \\
\hline
\end{tabular}

Western medicine medical visits, Chinese medicine medical visits, dental visits, total number of medical visits, payment points for Western medicine medical visits, payment points for Chinese medicine medical visits, and payment points for dental visits. The total number of medical visits for each disease code (based on the ICD-9CM) for 2015 were inputted. The data were then compiled and analyzed. The payment point information referred to the amount that the NHIA paid to medical agencies according to the ICD disease category and the medical services used other than the fixed registration fees that were paid by the patient. The payment points were approximately equivalent to NTD; however, the ratio of payment points to NTD amount was adjusted slightly annually. This data collection and research process were reviewed and approved by the Asia University Human Experiment Institutional Review Board (number: 10505001). The participants were informed about the purpose of the study, and that it was conducted in accordance with the Declaration of Helsinki.

\section{Statistics}

\section{Descriptive Statistical Analysis}

Analysis of individual basic information. The individual background variables (sex, age, education level, marital status, number of children, service seniority, current position, shift rotation status, smoking habits, drinking habits) are shown in percentages, means, and standard deviation.

\section{Independent Samples t-Test and One-Way Analysis of} Variance

The number of medical visits, and their number of medical visit points (means) difference among participants' personal background variables listed in Table 3 were examined. The significant alpha value is 0.05 .

\section{One Sample $t$-Test}

This involved comparing the participants' and general public's average number of medical visits and medical visit points to determine whether a significant difference resulted.

\section{Results}

This study collected the information from 150 participants. The complete demographic variables and their distribution are presented in Table 4. Men accounted for $92 \%$ of participants. The age distribution was 20-50 years old, and most had college education $(84.67 \%)$. Half of the participants were married, and the other half were not married. Most participants served for less than 10 years $(73.3 \%)$. Table 5 shows the participants' average number of Western medicine, Chinese medicine, and dental visits, and the average number of total annual medical visits. The participants' health insurance payment point distribution is presented in Table 6. The participants had a significantly higher number of Western medicine visitations, Western medicine health-care payment points, total number of medical visits, and total number of health-care payment points than did the same age groups in the general public. The within-group variables in the total number of medical visits included age, seniority, and job positions. The within-group variable for the total payment points only included age. The participants had a significantly higher number of medical visits for disease codes 460-519, 580-629, 680-709, 710-739, and 800-999 than did the same age groups in the Taiwanese general public, as shown in Table 7.

\section{Discussion}

This study used individual National Health Insurance records to compare the number of medical visits, health-care payment amounts, and the medical visit disease categories of firefighters 
Table 3 Variables and Candidate Items in the Demographic Data

\begin{tabular}{|c|c|c|}
\hline $\begin{array}{l}\text { Question } \\
\text { Number }\end{array}$ & $\begin{array}{l}\text { Individual } \\
\text { Variables }\end{array}$ & Choices \\
\hline I & Sex & Men, women \\
\hline 2 & Age & $\begin{array}{l}2 I-30 \text { years old; } \\
3 I-40 \text { years old; } \\
4 I-50 \text { years old; } \\
5 I-60 \text { years old }\end{array}$ \\
\hline 3 & Education level & $\begin{array}{l}\text { Junior high school or below; } \\
\text { high school (vocational); } \\
\text { college (vocational); } \\
\text { graduate school (graduated or } \\
\text { still attending) }\end{array}$ \\
\hline 4 & Marital status & $\begin{array}{l}\text { Not married; } \\
\text { Married; } \\
\text { divorced }\end{array}$ \\
\hline 5 & $\begin{array}{l}\text { Number of } \\
\text { children }\end{array}$ & $\begin{array}{l}\text { None; } \\
\text { One; } \\
\text { Two; } \\
\text { three or more }\end{array}$ \\
\hline 6 & $\begin{array}{l}\text { Service } \\
\text { seniority }\end{array}$ & $\begin{array}{l}5 \text { years or less; } \\
6-10 \text { years; } \\
\text { II-15 years; } \\
16-20 \text { years; } \\
21 \text { years or more }\end{array}$ \\
\hline 7 & $\begin{array}{l}\text { Current } \\
\text { position }\end{array}$ & $\begin{array}{l}\text { Supervisor (team leader or } \\
\text { higher); } \\
\text { nonsupervisory positions }\end{array}$ \\
\hline 8 & Shift status & $\begin{array}{l}\text { Normal hours; } \\
\text { work I day and off I day; } \\
\text { work } 2 \text { days and off I day }\end{array}$ \\
\hline 9 & Smoking habits & $\begin{array}{l}\text { Nonsmoker; } \\
\text { quit smoking; } \\
\text { still smoking }\end{array}$ \\
\hline 10 & Drinking habits & $\begin{array}{l}\text { Nondrinker; } \\
\text { quit drinking; } \\
\text { still drinking }\end{array}$ \\
\hline
\end{tabular}

who worked in shift rotations. The annual average number of outpatient medical visits by firefighters who worked in shift rotations was 9.57 times, whereas that of the general public was on average 7.75. On average, firefighters who worked in shift rotations used 7003 health insurance payment points in a year (approximately US\$230), and the general public used on average 4940 points for the same year (approximately US $\$ 165$ ). Medical visit for diseases such as respiratory diseases,
Table 4 Participants' Demographic Variables

\begin{tabular}{|c|c|c|c|}
\hline Items & & Numbers & $\begin{array}{l}\text { Percentage } \\
\%\end{array}$ \\
\hline Gender & $\begin{array}{l}\text { Male } \\
\text { Female }\end{array}$ & $\begin{array}{l}138 \\
12\end{array}$ & $\begin{array}{l}92 \\
8\end{array}$ \\
\hline Age & $\begin{array}{l}2 I-30 \\
3 I-40 \\
4 I-50 \\
5 I-60\end{array}$ & $\begin{array}{l}63 \\
66 \\
15 \\
6\end{array}$ & $\begin{array}{l}42 \\
44 \\
10 \\
4\end{array}$ \\
\hline Education & $\begin{array}{l}\text { High school } \\
\text { (vocational) } \\
\text { College (vocational) } \\
\text { Graduate institute }\end{array}$ & $\begin{array}{l}2 \\
127 \\
21\end{array}$ & $\begin{array}{l}1.33 \\
84.67 \\
14\end{array}$ \\
\hline Marriage & $\begin{array}{l}\text { Not married } \\
\text { Married } \\
\text { Divorced }\end{array}$ & $\begin{array}{l}74 \\
74 \\
2\end{array}$ & $\begin{array}{l}49.33 \\
49.33 \\
1.34\end{array}$ \\
\hline $\begin{array}{l}\text { Children } \\
\text { number }\end{array}$ & $\begin{array}{l}\text { None } \\
\text { One } \\
\text { Two } \\
\text { Three or more }\end{array}$ & $\begin{array}{l}85 \\
28 \\
34 \\
3\end{array}$ & $\begin{array}{l}56.67 \\
18.66 \\
22.67 \\
2\end{array}$ \\
\hline $\begin{array}{l}\text { Service } \\
\text { seniority }\end{array}$ & $\begin{array}{l}5 \text { or less } \\
6-10 \text { years } \\
11-15 \text { years } \\
16-20 \text { years } \\
21 \text { years or more }\end{array}$ & $\begin{array}{l}61 \\
49 \\
20 \\
8 \\
12\end{array}$ & $\begin{array}{l}40.67 \\
32.67 \\
13.33 \\
5.33 \\
8\end{array}$ \\
\hline $\begin{array}{l}\text { Current } \\
\text { position } \\
\text { Smoking }\end{array}$ & $\begin{array}{l}\text { Supervisor } \\
\text { Nonsupervisory } \\
\text { position } \\
\text { Nonsmoker }\end{array}$ & $\begin{array}{l}21 \\
129 \\
124\end{array}$ & $\begin{array}{l}14 \\
86 \\
82.67\end{array}$ \\
\hline & $\begin{array}{l}\text { Quit smoking } \\
\text { Still smoking }\end{array}$ & $\begin{array}{l}5 \\
21\end{array}$ & $\begin{array}{l}3.33 \\
14\end{array}$ \\
\hline $\begin{array}{l}\text { Drinking } \\
\text { habits }\end{array}$ & $\begin{array}{l}\text { Nondrinker } \\
\text { Quit drinking } \\
\text { Still drinking }\end{array}$ & $\begin{array}{l}99 \\
5 \\
46\end{array}$ & $\begin{array}{l}66 \\
3.33 \\
30.67\end{array}$ \\
\hline
\end{tabular}

urogenital diseases, skin and subcutaneous tissue diseases, musculoskeletal system and connective tissue diseases, and injuries and poisonings all indicated significance $(\mathrm{P}<0.05)$ compared with the norm. These diseases are related to firefighters' work. Firefighters' main job is to provide disaster relief and rescue. During disasters, smoke and toxic substances that are created by a fire can significantly damage firefighters' 
Table 5 Distribution of Medical Visits. Data is Represented as the Mean (SD). *Denote $P<0.05 ; * * *<<0.00$ I

\begin{tabular}{|c|c|c|c|c|c|c|c|c|}
\hline \multicolumn{2}{|c|}{ Individual Demographic VariableS } & $\begin{array}{l}\text { Western } \\
\text { Medicine }\end{array}$ & PI & $\begin{array}{l}\text { Chinese } \\
\text { Medicine }\end{array}$ & $\mathbf{P 2}$ & Dentist & $\begin{array}{l}\text { Total Medical Visit } \\
\text { Count }\end{array}$ & $\mathbf{P 3}$ \\
\hline \multicolumn{2}{|l|}{$\begin{array}{l}\text { Norm mean } \\
\text { Subject mean }\end{array}$} & $\begin{array}{l}5.24 \\
6.27\end{array}$ & $0.041^{*}$ & $\begin{array}{l}1.26 \\
1.75\end{array}$ & 0.180 & $\begin{array}{l}1.25 \\
1.55\end{array}$ & $\begin{array}{l}7.75 \\
9.57\end{array}$ & $0.010^{*}$ \\
\hline Sex & $\begin{array}{l}\text { Man } \\
\text { Woman }\end{array}$ & $\begin{array}{l}5.95(5.56) \\
10(10.55)\end{array}$ & $0.028 *$ & $\begin{array}{l}1.8(4.6) \\
1.08(1.51)\end{array}$ & 0.590 & $\begin{array}{l}1.54(2.04) \\
1.67(1.56)\end{array}$ & $\begin{array}{l}9.3(8.39) \\
12.75(10.48)\end{array}$ & 0.182 \\
\hline Age & $\begin{array}{l}21-30 \text { years } \\
31-40 \text { years } \\
41-50 \text { years } \\
51-60 \text { years }\end{array}$ & $\begin{array}{l}5.52(5.25) \\
6.14(6.45) \\
7.27(6.39) \\
13.17(7.91)\end{array}$ & $0.029 *$ & $\begin{array}{l}1.37(2.72) \\
1.52(3.06) \\
1.4(2.77) \\
9.17(16.76)\end{array}$ & $0.000369 * * *$ & $\begin{array}{l}1.67(1.91) \\
1.55(2.14) \\
1.2(1.9) \\
1.33(1.97)\end{array}$ & $\begin{array}{l}8.56(7) \\
9.2(8.1) \\
9.87(9.04) \\
23.67(15.9)\end{array}$ & $0.000444 * * *$ \\
\hline Education level & $\begin{array}{l}\text { High school } \\
\text { (vocational) } \\
\text { College (vocational) } \\
\text { Graduate institute }\end{array}$ & $\begin{array}{l}10(8.49) \\
6.13(5.95) \\
6.81(7.34)\end{array}$ & 0.620 & $\begin{array}{l}0.5(0.7 \mathrm{I}) \\
1.83(4.65) \\
1.33(3.09)\end{array}$ & 0.824 & $\begin{array}{l}0(0) \\
1.61(1.96) \\
1.38(2.31)\end{array}$ & $\begin{array}{l}10.5(9.19) \\
9.57(8.68) \\
9.52(8.32)\end{array}$ & 0.988 \\
\hline Marital status & $\begin{array}{l}\text { Not married } \\
\text { Married } \\
\text { Divorced }\end{array}$ & $\begin{array}{l}5.62(5.46) \\
6.91(6.82) \\
7(1.41)\end{array}$ & 0.443 & $\begin{array}{l}1.45(2.86) \\
2.04(5.56)\end{array}$ & 0.414 & $\begin{array}{l}1.57(1.72) \\
1.54(2.28) \\
1.5(0.71)\end{array}$ & $\begin{array}{l}8.64(7.28) \\
10.49(9.64)\end{array}$ & 0.187 \\
\hline $\begin{array}{l}\text { Number of } \\
\text { children }\end{array}$ & $\begin{array}{l}\text { None } \\
\text { One } \\
\text { Two } \\
\text { Three or more }\end{array}$ & $\begin{array}{l}5.87(5.70) \\
5.82(5.18) \\
7.97(7.82) \\
2.67(2.08)\end{array}$ & 0.249 & $\begin{array}{l}1.51(2.99) \\
1.46(3.27) \\
2.59(7.47) \\
1.67(2.89)\end{array}$ & 0.665 & $\begin{array}{l}1.53(1.75) \\
1.71(2.31) \\
1.53(2.42) \\
I(1)\end{array}$ & $\begin{array}{l}8.91(7.68) \\
9(6.94) \\
12.09(11.46) \\
5.33(5.86)\end{array}$ & 0.233 \\
\hline Service seniority & $\begin{array}{l}0-5 \text { years } \\
6-10 \text { years } \\
11-15 \text { years } \\
16-20 \text { years } \\
21 \text { years or more }\end{array}$ & $\begin{array}{l}4.92(4.51) \\
6.53(5.8) \\
5.8(6.9) \\
10.88(10.15) \\
9.83(8.21)\end{array}$ & $0.018^{*}$ & $\begin{array}{l}1.51(2.81) \\
1.51(2.87) \\
1.35(3.37) \\
1.63(4.21) \\
4.67(12.09)\end{array}$ & 0.224 & $\begin{array}{l}1.64(1.84) \\
1.65(2.13) \\
1.05(1.67) \\
1.5(3.12) \\
1.58(2.15)\end{array}$ & $\begin{array}{l}8.07(6.53) \\
9.69(7.39) \\
8.2(8.79) \\
14(11.122) \\
16.08(15.42)\end{array}$ & $0.020 *$ \\
\hline Current position & $\begin{array}{l}\text { Supervisor } \\
\text { Nonsupervisory } \\
\text { position }\end{array}$ & $\begin{array}{l}8.33(7.28) \\
5.94(5.91)\end{array}$ & 0.098 & $\begin{array}{l}3.38(9.43) \\
1.48(2.91)\end{array}$ & 0.068 & $\begin{array}{l}1.62(2.46) \\
1.54(1.93)\end{array}$ & $\begin{array}{l}13.33(13.1) \\
8.96(7.5)\end{array}$ & $0.029 *$ \\
\hline Smoking habits & $\begin{array}{l}\text { Nonsmoker } \\
\text { Quit smoking } \\
\text { Still smoking }\end{array}$ & $\begin{array}{l}6.27(6.15) \\
12(9.33) \\
4.90(4.70)\end{array}$ & 0.067 & $\begin{array}{l}1.44(2.94) \\
3.2(4.6) \\
3.19(9.26)\end{array}$ & 0.188 & $\begin{array}{l}1.42(1.82) \\
2.8(3.56) \\
2.05(2.47)\end{array}$ & $\begin{array}{l}9.14(7.72) \\
18(12.47) \\
10.14(11.47)\end{array}$ & 0.072 \\
\hline Drinking habits & $\begin{array}{l}\text { Nondrinker } \\
\text { Quit drinking } \\
\text { Still drinking }\end{array}$ & $\begin{array}{l}6.72(6.4 I) \\
5.6(7.83) \\
5.39(5.4)\end{array}$ & 0.471 & $\begin{array}{l}1.88(5.04) \\
0.2(0.45) \\
1.63(3.06)\end{array}$ & 0.697 & $\begin{array}{l}1.41(1.7) \\
1.6(1.82) \\
1.85(2.56)\end{array}$ & $\begin{array}{l}10.01(8.9) \\
7.4(8.08) \\
8.87(8.02)\end{array}$ & 0.900 \\
\hline
\end{tabular}

respiratory system. ${ }^{13}$ Musculoskeletal system and connective tissue diseases, injuries, and poisonings are also related to disaster relief. This indicates that a survey of firefighters' health insurance medical history can reveal diseases that are related to their job. Furthermore, the participants worked in 2 days on/ 1 day off shift rotations, which suggested that they were affected by the abnormal resting time of shift rotations.

Compared with other research methods, surveys and medical record statistics are sampling survey methods that do not reveal participants' disease orientation. However, other studies have first targeted the specific research topic before appropriate research tools were used to survey it. For example, the research topic in reference ${ }^{16}$ was depression, and the questionnaire used is the Center for Epidemiologic Studies Depression Scale. The participants knew that the study was about depression. However, this type of focused research can exaggerate the importance of the phenomenon because the participant focuses on it. However, other diseases or symptoms that are related to firefighters may not be understood because the participants and researchers overlook them. By contrast, this study used medical visit data as a basis to accurately understand the entire disease distribution of firefighters. The comprehensive health-care database in Taiwan can be used to compare 
Table 6 Distribution of Payment Points Data is Represented as Mean (Std). *Denote P<0.05; **P<0.0I; ***p<0.00I

\begin{tabular}{|c|c|c|c|c|c|c|c|c|}
\hline \multicolumn{2}{|c|}{ Individual Demographic VariableS } & $\begin{array}{l}\text { Western } \\
\text { Medicine }\end{array}$ & PI & $\begin{array}{l}\text { Chinese } \\
\text { Medicine }\end{array}$ & $\mathbf{P 2}$ & Dentist & $\begin{array}{l}\text { Total Payment } \\
\text { Points }\end{array}$ & $\mathbf{P 3}$ \\
\hline \multicolumn{2}{|l|}{$\begin{array}{l}\text { Norm mean } \\
\text { Subject mean }\end{array}$} & $\begin{array}{l}274 I \\
4079\end{array}$ & $0.0031 * *$ & $\begin{array}{l}639 \\
900\end{array}$ & 0.128 & $\begin{array}{l}1558 \\
2026\end{array}$ & $\begin{array}{l}4940 \\
7003\end{array}$ & $0.0003^{* * *}$ \\
\hline Sex & $\begin{array}{l}\text { Man } \\
\text { Woman }\end{array}$ & $\begin{array}{l}3858.02(5237.14) \\
6616.67(7371.57)\end{array}$ & 0.093 & $\begin{array}{l}915.03(2140.81) \\
715.5(1274.96)\end{array}$ & 0.751 & $\begin{array}{l}2015.39(3211.24) \\
2142.33(2004.79)\end{array}$ & $\begin{array}{l}6788.44 \text { (6778.98) } \\
9474.5 \text { (7501.85) }\end{array}$ & 0.194 \\
\hline Age & $\begin{array}{l}21-30 a \\
31-40 a \\
41-50 a \\
51-60 b\end{array}$ & $\begin{array}{l}3163.41(3866.18) \\
4443.94(6413.42) \\
3763.73(3818) \\
10,459.33 \\
(8094.47)\end{array}$ & $0.014 *$ & $\begin{array}{l}775.67(1346.64) \\
768.79(1605.59) \\
723.93(1318.27) \\
4065.67(7472.23)\end{array}$ & $0.0018 * *$ & $\begin{array}{l}2503.27(3647.08) \\
1799.26(2843.56) \\
1305(2 \mid 14.93) \\
1300(1764.27)\end{array}$ & $\begin{array}{l}6442.35(5377.93) \\
7011.99(7378.56) \\
5792.67(5388.74) \\
15,825(12,224.8)\end{array}$ & $0.011^{*}$ \\
\hline Education level & $\begin{array}{l}\text { High school } \\
\text { (vocational) } \\
\text { College (vocational) } \\
\text { Graduate institute }\end{array}$ & $\begin{array}{l}3885.06(5394.14) \\
5268.29(5832.68)\end{array}$ & 0.283 & $\begin{array}{l}45(63.64) \\
959.592189 .86) \\
614.38 \text { (1384.59) }\end{array}$ & 0.661 & $\begin{array}{l}0 \\
2180.84(3258.11) \\
1279.29(2198.36)\end{array}$ & $\begin{array}{l}13,94 \mid(15,074.1) \\
6867.84(6887.03) \\
7161.95(5881.35)\end{array}$ & 0.350 \\
\hline Marital status & $\begin{array}{l}\text { Not married } \\
\text { Married } \\
\text { Divorced }\end{array}$ & $\begin{array}{l}3685.91 \text { (4672.23) } \\
4324.3(6114.07) \\
9526(6454.47)\end{array}$ & 0.285 & $\begin{array}{l}849.03(1574.88) \\
947.79(2489.39)\end{array}$ & 0.501 & $\begin{array}{l}2274.73(3317.95) \\
1781.04(2966.36) \\
1852.5(1438.96)\end{array}$ & $\begin{array}{l}6809.66(6218.92) \\
7191.9(7452.73)\end{array}$ & 0.734 \\
\hline $\begin{array}{l}\text { Number of } \\
\text { children }\end{array}$ & $\begin{array}{l}\text { None } \\
\text { One } \\
\text { Two } \\
\text { Three or more }\end{array}$ & $\begin{array}{l}3625.97(4486.38) \\
4046.64(6878.67) \\
5525.44(6396.07) \\
809.67(439.44)\end{array}$ & 0.257 & $\begin{array}{l}820.6(1561.8) \\
634.61(1358.64) \\
1258.27(3346.6) \\
1519.67(2632.14)\end{array}$ & 0.608 & $\begin{array}{l}2177.27(3243.49) \\
2024.39(3106.37) \\
1774(3025.54) \\
588.33(511.721)\end{array}$ & $\begin{array}{l}6623.84(6163.78) \\
6705.64(6941.81) \\
8557.71(8406.78) \\
2917.67(3381.31)\end{array}$ & 0.375 \\
\hline Service seniority & $\begin{array}{l}0-5 \text { years } \\
6-10 \text { years } \\
11-15 \text { years } \\
16-20 \text { years } \\
21 \text { years or more }\end{array}$ & $\begin{array}{l}2868.07(3780.42) \\
3818.18(4306.75) \\
5751.1(9077.93) \\
6936.25(6093.89) \\
6604.33(7231.74)\end{array}$ & $0.042 *$ & $\begin{array}{l}849.77 \text { (1382.62) } \\
849.73 \text { (1673.66) } \\
549.7 \text { (1399.79) } \\
776.63(2001.14) \\
2015(5342.94)\end{array}$ & 0.396 & $\begin{array}{l}2605.07(3749.62) \\
1861.41(2822.7) \\
1184.5(1875.95) \\
1526.13(3345.54) \\
1484.58(2010.05)\end{array}$ & $\begin{array}{l}6322.90(5684.5) \\
6529.33(5710.17) \\
7485.3(9208.59) \\
9239(6523.19) \\
10,103.92(11,210.05)\end{array}$ & 0.377 \\
\hline Current position & $\begin{array}{l}\text { Supervisor } \\
\text { Nonsupervisory } \\
\text { position }\end{array}$ & $\begin{array}{l}6228.24(7070.87) \\
3728.79(5097.92)\end{array}$ & 0.051 & $\begin{array}{l}|486.8|(4 \mid 82.64) \\
803.39 \text { (1499.68) }\end{array}$ & 0.164 & $\begin{array}{l}1527.57(2480.85) \\
2106.61(3221.02)\end{array}$ & $\begin{array}{l}9242.62(9771.82) \\
6226.38\end{array}$ & 0.107 \\
\hline Smoking habits & $\begin{array}{l}\text { Nonsmoker } \\
\text { Quit smoking } \\
\text { Still smoking }\end{array}$ & $\begin{array}{l}3971.61 \text { (5280.4I) } \\
8863.4(8431.50) \\
3571.91(5496.01)\end{array}$ & 0.067 & $\begin{array}{l}744.93(1380.6) \\
1350.6(1906.76) \\
\text { I70I.7| (4357.29) }\end{array}$ & 0.133 & $\begin{array}{l}1945.8(3111.41) \\
2577(2751.10) \\
2365.14(3401.37)\end{array}$ & $\begin{array}{l}6662.34(6 \mid 17.92) \\
12,79 \mid(9389.7) \\
7638.76(96 \mid 1.67)\end{array}$ & 0.132 \\
\hline Drinking habits & $\begin{array}{l}\text { Nondrinker } \\
\text { Quit drinking } \\
\text { Still drinking }\end{array}$ & $\begin{array}{l}4137.23(5396.43) \\
5023.6(9396.96) \\
3850.07(5217.51)\end{array}$ & 0.887 & $\begin{array}{l}934.81(2266.6) \\
71.8(160.55) \\
912.07(1757.97)\end{array}$ & 0.667 & $\begin{array}{l}1755.94(2319.43) \\
2687.8(3102.93) \\
2533.80(4397.33)\end{array}$ & $\begin{array}{l}6827.98(6566.43) \\
7783.2(9446.64) \\
7295.94(7305.94)\end{array}$ & 0.900 \\
\hline
\end{tabular}

the averages in similar age groups among the general public and to highlight disease types in which firefighters have a higher number of medical visits and medical care costs than does the general population. This is an interesting research method, and its advantages are shown in this study.

One advantage of this study is that it is built on Taiwan's comprehensive National Health Insurance system. The normal medical visit characteristics of the general public in the same area can be compared with publicly downloaded data. The convenient information system allows for easy access to individual medical visit information. Therefore, this study only required consent from the participants to connect to the Internet with the health insurance IC card and download their information. This easy access to information and the study method cannot be replicated in every area. However, this type of study method can be extended to health studies of participants in other special groups, such as with other work fields or work with special routines that are combined with other special topics (insomnia, anxiety, and patients with 
Table 7 Total Number of Medical Visits of Participants and the General Public by International Statistical Classification of Diseases and Related Health Problems (ICD-9) Disease Categorization

\begin{tabular}{|c|c|c|c|c|}
\hline $\begin{array}{l}\text { ICD-9 } \\
\text { Number }\end{array}$ & Diseases of ICD-9 Code & $\begin{array}{l}\text { Firefighters Aged } \\
20-60 \text { Years }\end{array}$ & $\begin{array}{l}\text { General Public (Aged 20-60 } \\
\text { Years Old) }\end{array}$ & $\mathbf{P}$ \\
\hline $001-139$ & Infectious and Parasitic Diseases & 0.37 & 0.19 & $0.25 I^{a, b, c}$ \\
\hline $140-239$ & Neoplasms & 0.09 & 0.1 & 0.905 \\
\hline $240-279$ & $\begin{array}{l}\text { Endocrine, Nutritional and Metabolic Diseases, and } \\
\text { Immunity Disorders }\end{array}$ & 0.21 & 0.16 & $0.490^{\mathrm{a}}$ \\
\hline $280-289$ & Diseases of the Blood and Blood-forming Organs & 0 & 0.03 & n.a \\
\hline $290-319$ & Mental Disorders & 0.09 & 0.1 & $0.828^{a, b, c, c}$ \\
\hline $320-359$ & Diseases of the Nervous System & 0.03 & 0.05 & 0.216 \\
\hline $360-389$ & Diseases of Sense Organs & 0.43 & 0.28 & 0.072 \\
\hline $390-459$ & Diseases of the Circulatory System & 0.31 & 0.16 & $0.134^{\mathrm{a}, \mathrm{b}}$ \\
\hline $460-519$ & Diseases of the Respiratory System & 2.03 & 0.64 & $1.16 \mathrm{e}-07$ \\
\hline $520-579$ & Diseases of the Digestive System & 0.67 & 0.65 & 0.834 \\
\hline $580-629$ & Diseases of the Genitourinary System & 0.68 & 0.26 & $0.0002^{a, b, c}$ \\
\hline $630-676$ & $\begin{array}{l}\text { Complications of Pregnancy, Childbirth, and The } \\
\text { Puerperium }\end{array}$ & 0.03 & 0.06 & 0.115 \\
\hline $680-709$ & Diseases of the Skin and Subcutaneous Tissue & 0.82 & 0.34 & $0.0010^{d}$ \\
\hline $710-739$ & $\begin{array}{l}\text { Diseases of the Musculoskeletal System and } \\
\text { Connective Tissue }\end{array}$ & 0.79 & 0.33 & 0.0012 \\
\hline $740-759$ & Congenital Anomalies & 0.01 & 0.01 & 0.7233 \\
\hline 780-799 & Symptoms, Signs, and III-defined Conditions & 0.67 & 0.44 & 0.079 \\
\hline $800-999$ & Injury and Poisoning & 0.79 & 0.32 & 0.0036 \\
\hline
\end{tabular}

Notes: Individual demographic variables that achieved significance $(P<0.05)$ : ${ }^{a}$ Age, ${ }^{b}$ Service seniority, ${ }^{\mathrm{C}}$ Current position, ${ }^{\mathrm{d}}$ Smoking habits.

chronic diseases). This interesting research method can be used to discover new phenomena that were not observed previously.

\section{Conclusion}

By reviewing individual medical visit records in Taiwan's National Health Insurance database, this study discovered that firefighters who worked on shift rotations had a higher number of outpatient visits and higher outpatient medical cost expenditures than did people in the same age group in Taiwan. This was particularly true for respiratory diseases, urogenital diseases, skin and subcutaneous tissue diseases, musculoskeletal system and connective tissue diseases, and injuries or poisonings that were related to firefighters working on shift rotations. This type of research method may be able to uncover new phenomena that were not observed previously, which renders this method worth investigation.

\section{Acknowledgments}

The authors would like to thank the subjects of fire agencies of Taichung City Government, for their kind cooperation. This research was funded by Asia University and China Medical University Hospital with grant number ASIA-106-CMUH-25

\section{Disclosure}

The authors report no conflicts of interest in this work.

\section{References}

1. Moreno CR, Marqueze EC, Sargent C, Wright KP Jr, Ferguson SA, Tucker P. Working time society consensus statements: evidence-based effects of shift work on physical and mental health. Ind Health. 2019;57:139-157. doi:10.2486/indhealth.SW-1

2. Loef B, Van Baarle D, Van Der Beek AJ, Sanders EA, Bruijning-Verhagen P, Proper KI. Shift work and respiratory infections in health-care workers. Am J Epidemiol. 2019;188:509-517. doi:10.1093/aje/kwy258 
3. Jeong KS, Ahn Y-S, Jang T-W, et al. Sleep assessment during shift work in Korean firefighters: a cross-sectional study. Saf Health Work. 2019;10:254-259. doi:10.1016/j.shaw.2019.05.003

4. Kazronian S, Zakerian SA, Mortezapour A, Saraji GN, Hosseini M. Influence of 24-hours shift work system on occupational stress among iranian firefighters. Archives Adv Biosci. 2019;10.

5. Wen-Feng Chiu Y-H-H, Tang W-L. The study of investigation on firefighter line-of-duty injuries and the post-incident illness. National Taiwan Police College Bulletin. 2009;4:61-86.

6. Johnson CC, Vega L, Kohalmi AL, Roth JC, Howell BR, Van Hasselt VB. Enhancing mental health treatment for the firefighter population: understanding fire culture, treatment barriers, practice implications, and research directions. Prof Psychol Res Pr. 2019;51:304-311. doi:10.1037/ pro0000266

7. Khan WAA, Conduit R, Kennedy GA, Abdullah Alslamah A, Ahmad Alsuwayeh M, Jackson ML. Sleep and mental health among paramedics from Australia and Saudi Arabia: a comparison study. Clocks Sleep. 2020;2:246-257. doi:10.3390/clockssleep2020019

8. Administration, N.H.I. My health bank. Availabe from: https://www. youtube.com/watch?v=km-BATMxMjA\&feature=youtu.be. Accessed January 19, 2021.

9. Lee M-C, Bariol SV. Evolution of stone management in Australia. BJU Int. 2011;108:29-33. doi:10.1111/j.1464-410X.2011.10695.x

10. Turvey C, Klein D, Fix G, et al. Blue Button use by patients to access and share health record information using the Department of Veterans Affairs' online patient portal. J Am Med Informatics Association. 2014;21:657-663. doi:10.1136/amiajnl-2014-002723

11. NHIA. My Health Bank. Availabe from: https://www.nhi.gov.tw/ English/Content_List.aspx?n=21D194F3C675DB0E\&topn= BCB2B0D2433F6491. Accessed January 27.

12. McCarthy EP, Iezzoni LI, Davis RB, et al. Does clinical evidence support ICD-9-CM diagnosis coding of complications? Med Care. 2000;38:868-876. doi:10.1097/00005650-200008000-00010

13. Games KE, Winkelmann ZK, Eberman LE. Physical exertion diminishes static and dynamic balance in firefighters. Int $J$ Athletic Therapy Training. 2020;1:1-5.

14. Kazemi R, Zare S, Hemmatjo R. Comparison of melatonin profile and alertness of firefighters with different work schedules. J Circadian Rhythms. 2018;16:16. doi:10.5334/jcr.155

15. Kim HW, Jung S-M, Choi YS, et al. Sleep patterns of firefighters with shift working schedules in Seoul Metropolitan area. Sleep Med Res. 2017;8:68-75. doi:10.17241/smr.2017.00059

16. Saijo Y, Ueno T, Hashimoto Y. Twenty-four-hour shift work, depressive symptoms, and job dissatisfaction among Japanese firefighters Am J Ind Med. 2008;51:380-391. doi:10.1002/ajim.20571

17. Kaikkonen P, Lindholm H, Lusa S. Physiological load and psychological stress during a 24-hour work shift among Finnish firefighters. J Occupational Environmental Med. 2017;59:41-46. doi:10.1097/ JOM.0000000000000912

Risk Management and Healthcare Policy

\section{Publish your work in this journal}

Risk Management and Healthcare Policy is an international, peerreviewed, open access journal focusing on all aspects of public health, policy, and preventative measures to promote good health and improve morbidity and mortality in the population. The journal welcomes submitted papers covering original research, basic science, clinical \& epidemiological studies, reviews and evaluations,
18. Sumińska S, Nowak K, Łukomska B, Cygan H. Cognitive functions of shift workers: paramedics and firefighters. An EEG study. Int $j$ Occupational Safety Ergonomics. 2020;1-21.

19. Petersen KU, Pedersen JE, Bonde JP, Ebbehøj NE, Hansen J. Mortality in a cohort of Danish firefighters; 1970-2014. Int Arch Occup Environ Health. 2018;91:759-766. doi:10.1007/s00420-0181323-6

20. Sritharan J, Pahwa M, Demers PA, Harris SA, Cole DC, Parent M-E. Prostate cancer in firefighting and police work: a systematic review and meta-analysis of epidemiologic studies. Environmental Health. 2017;16:124. doi:10.1186/s12940-017-0336-Z

21. Choi B, Schnall P, Dobson M. Twenty-four-hour work shifts, increased job demands, and elevated blood pressure in professional firefighters. Int Arch Occup Environ Health. 2016;89:1111-1125. doi:10.1007/s00420-016-1151-5

22. Chappel SE, Aisbett B, Vincent GE, Ridgers ND. Firefighters' physical activity across multiple shifts of planned burn work. Int J Environ Res Public Health. 2016;13:973. doi:10.3390/ ijerph13100973

23. Sommerfeld A, Wagner SL, Harder HG, Schmidt G. Habital health and firefighters: an intervention and interviews with Canadian firefighters. J Loss Trauma. 2017;22:307-324. doi:10.1080/ 15325024.2017.1284515

24. Choi B, Dobson M, Schnall P, Garcia-Rivas J. 24-hour work shifts, sedentary work, and obesity in male firefighters. Am J Ind Med. 2016;59:486-500. doi:10.1002/ajim.22572

25. Strauß M, Foshag P, Przybylek B, et al. Occupation and metabolic syndrome: is there correlation? A cross sectional study in different work activity occupations of German firefighters and office workers. Diabetol Metab Syndr. 2016;8:57. doi:10.1186/s13098-016-0174-0

26. Kodom-Wiredu JK. The relationship between firefighters' work demand and work-related musculoskeletal disorders: the moderating role of task characteristics. Saf Health Work. 2019;10:61-66. doi:10.1016/j.shaw.2018.05.004

27. McGinnis K, Games K. Contributing factors to structural firefighter injury. J Sci Med Sport. 2017;20:S91-S92. doi:10.1016/j. jsams.2017.07.012

28. Kim HD, An YS, Kim DH, Jeong KS, Ahn YS. An overview of compensated work-related injuries among Korean firefighters from 2010 to 2015. Ann Occupational Environmental Med. 2018;30:57. doi:10.1186/s40557-018-0268-2 